\title{
A study of best management practices for enhancing productivity in building projects: construction methods perspectives
}

\author{
Argaw Tarekegn Gurmu, Ajibade Ayodeji Aibinu and Toong Khuan Chan \\ Melbourne School of Design, The University of Melbourne, Australia
}

\begin{abstract}
This research investigates management practices that have the potential to enhance productivity in building projects by focusing on construction methods. In phase 1 of the study, face-to-face interviews with nineteen experts were conducted to identify the best management practices for construction methods. The qualitative data analysis reached saturation and resulted in a list of best practices for construction methods that are relevant to the local industry. The second phase used an industry-wide survey to prioritize the best practices. Accordingly, project start-up plan, traffic control plan, machinery positioning strategy, project completion plan, and dynamic site layout plan were shown to be the top five best practices for construction methods. The study also revealed that high levels of implementation of best practices are associated with low levels of project delays. The use of best practices also varied according to the project costs. There were no discernible differences between the top five best practices. The authors suggest that they should be implemented jointly to improve productivity in building projects. Contractors could use the logistic regression model developed, to predict the probability of exceeding a baseline productivity factor and, on that basis, implement corrective actions to achieve the desired level of productivity.
\end{abstract}

Keywords: Best management practices, construction methods, construction productivity, Australia.

Paper type: Research article

\section{Introduction}

Productivity improvement in the construction industry is important for the growth of a country's economy at large and profitability of contractors in particular. Productivity is described as the ratio of output to input (Jarkas and Bitar, 2011). In this study, output represents the value of a completed building project in dollars and input refers to project duration in days. Previous studies indicate that management related problems such as lack of integration of works of sub-contractors, out of sequence work assignments, work overload, and poor site layouts are among the major factors impacting project productivity (Dai et al., 2009). However, these problems can be reduced by adopting best management practices that are suitable for particular project types such as building, infrastructure, and industrial. Best management practices are processes that, when executed effectively, lead to enhanced project performance (CII, 2016). Construction management practices that have the potential to improve productivity could be categorized into: construction methods (Caldas et al., 2014);

\footnotetext{
Copyright: Construction Economics and Building 2016. (C) 2016 Argaw Gurmu, Ajibade Aibinu and Toong Chan. This is an Open Access article distributed under the terms of the Creative Commons Attribution 4.0 Unported (CC BY 4.0) License (https://creativecommons.org/licenses/by/4.0/), allowing third parties to copy and redistribute the material in any medium or format and to remix, transform, and build upon the material for any purpose, even commercially, provided the original work is properly cited and states its license.
}

Citation: Gurmu, A.T., Aibinu, A.A. and Chan, T.K. 2016. A study of best management practices for enhancing productivity in building projects: construction methods perspectives, Construction Economics and Building, 16(3), 1-19. DOI: http://dx.doi.org/10.5130/AJCEB.v16i3.4882

Corresponding author: Argaw Gurmu; Email-agurmu@student.unimelb.edu.au

Publisher: University of Technology Sydney (UTS) ePress 
construction materials management (long lead materials identification, materials procurement and delivery plans, and inspection and test plans) (Bell and Stukhart, 1987); construction equipment and tools management (procurement plans for machinery, maintenance of equipment and tools and productivity analysis of construction equipment) (Stewart, 2002); execution approaches (buildability review, short interval plans, work package, and the scope of works) (Lam, Wong and Chan, 2006); human resource management (crew composition, skill assessment, training and career development plans) (Hewage, Gannoruwa and Ruwanpura, 2011); health and safety practices (housekeeping, task safety analysis, tool box meetings, and safety training) (Hinze and Wilson, 2000). In this research, construction methods best practices were investigated while pre-construction activities such as buildability reviews were not considered. Although previous studies identified best practices for infrastructure and industrial projects, they cannot be directly adopted for building projects. For instance, while traffic control plan, project completion plan, communications, coordination, and agreements are identified as best practice for infrastructure projects, they are not included in the list of best practices for industrial projects (Nasir, 2013). Moreover, the priority given to some of the common elements of both project types are different. Thus, building projects could have different best practices. However, a little research has been done on what these best practices might be and which of them should be given priority in the context of Victoria, Australia. The objectives of this study are:

- To identify best practices for construction methods which have the potential to improve productivity in building projects

- To prioritize the best practices for construction methods and develop a tool to measure them

- To develop a logistic regression model that predicts the probability of exceeding a specific productivity value based on a score of the best practices for construction methods

\section{Literature review}

\section{Construction methods influencing productivity in construction projects}

Project management methods are defined as a system of practices, techniques, procedures, and rules used by those who work in the discipline (PMI, 2013). In construction projects, the techniques of integration of different schedules; schedule controlling methods; mechanisms used in the preparation of site layout, project start-up and completion procedures; and investigation of suitable technologies are some of the methods considered as best practices.

Arditi and Mochtar (1996) suggested integration of management functions is one of the areas where productivity gain could be obtained. Caldas et al. (2014) confirmed that integrated schedule is one of the best practices for improving productivity in industrial projects. In the context of the Victorian construction industry, since many sub-contractors are involved in the construction of a particular building project, principal contractors might require techniques for integrating the schedules of these sub-contractors. According to ABS, 78\% of building construction works are executed by small and medium firms (Australian Bureau of Statistics, 2013).

Scheduled overtime has a positive impact on productivity, as it builds the morale of employees (CII, 2013a). Hanna et al. (2008) found that shift schedule is effective as compared to overtime and overmanning in reducing the project duration. The authors opined that the use of shift schedule reduces physical fatigue and site congestion that could occur if overtime and overmanning practices are implemented. Given the working hours restrictions set by various authorities in Victoria, such as Environmental Protection Authority, adopting different working 
hours strategies such as scheduled overtime could be important practices for delivery of building projects within the contract time.

Schedule execution and management refers to schedule controlling techniques such as methods for measuring work progress, analysing data, reporting results and taking corrective actions. Some of the techniques include units completed, incremental milestone, start/finish, supervisor judgment, S-Curve, time variance and forecast, analysis tree, percent complete report, activity crashing and activity overlapping (Attalla, 1997). Delay in the progress of a particular subcontractor could affect the progress of others and lead to overall project delay. Thus, implementation of the schedule controlling techniques might be an important practice for principal contractors that manage numerous sub-contractors in the context of Victoria.

Dynamic site layout refers to a sequence of layouts each of which is used for a discrete time interval or for a certain project phase, and together covering the entire duration of a construction project (Tommelein and Zouein, 1993). As most building projects in the central business district of Melbourne, Australia, have restricted working spaces, dynamic site layout plans could help principal contractors in reducing congestion on sites. By using dynamic layout plan, some parts of a building under construction can be used as store, office and other temporary facility allowing early start of the external works.

Choi and Harris (1992) proposed a mathematical model for determining the most suitable tower crane location for building projects. Safe Work Australia implemented a code of practice to assist contractors in preparing good traffic management plans by providing information about traffic signs, distance between pedestrians and vehicles, and vehicles movement (Safe Work Australia, 2014). In Victoria, as most construction materials are imported from overseas, any loss or damage to them could incur loss of productivity due to unavailability of the materials locally. Thus, site security plans might be an important practice to reduce theft and loss of materials. Investigation of the most appropriate location for a crane could also be a significant practice in Victoria. If a crane is positioned wrongly, its relocation cost could be high. Thus, developing a strategy to position the crane using different models might be important for principal contractors in Victoria, to reduce cost and increase productivity. Traffic control plans could also be a significant practice as there are various local regulations about traffic such as Road Safety (Traffic Management) Regulations 2009 that could influence building projects' performance.

Fangel (1984) recommended preparation of a project management manual that contains project start-up details. The author also suggested project start-up meetings prior to commencing a construction project. Kerzner (2010) proposed project kick-off meetings as one of the best practices that should be included in the project start-up process. Nasir (2013) confirmed that project start-up and completion plans, and new technologies are the best practices to enhance productivity in infrastructure projects. In the context of building projects in Victoria, various sub-contractors finish their works at different times and a principal contractor should plan when to receive certificates of the completed works by each sub-contractor. Thus, completion plans could be a significant practice during handover of a building project to the client. New technologies might also be important. For instance, to detect clashes between different services in a building, different software could be used.

\section{Research method}

\section{The research context}

The construction sector in Victoria, Australia is dominated by a few large contractors that engage numerous small companies. In 2015, the proportion of companies involved in building construction were $0.06 \%, 0.78 \%$ and $99.15 \%$ for firms employing over 200 workers, $20-199$ 
workers, and 0-19 workers respectively (Australian Bureau of Statistics, 2016). The local construction industry is characterized by the presence of a strong Construction, Forestry, Mining and Energy Union that prepares a calendar for construction sites (CFMEU, 2016). The Union signs an enterprise bargaining agreement in which minimum payments and other working conditions are agreed between contractor and Union. Regulatory bodies such as the Fair Work Commission stipulate minimum wages, working hours, overtime payments, penalty rates and other employment conditions in building construction projects. Accordingly, the ordinary number of working hours is 38 per week between 7:00am and 6:00pm (Fair Work Commission, 2016). In addition, Environment Protection Authority Victoria (EPA) has a guideline to control noise from building projects. Accordingly, normal working hours are restricted to 7:00 am to 6:00 pm during weekdays and 7:00 am to 1:00 pm on Saturdays (EPA, 2016). Most construction materials are imported from overseas due to increasing investment costs in the manufacturing sector (Wheeldon, 2012). Prefabricated construction systems are increasing at about 5\% per year (PrefabAUS, 2014).

\section{Measurement of management practices for construction methods and construction projects' productivity}

Management practices are measured by using validated standard questionnaires. Bloom and Van Reenen (2007) developed a technique to measure management practices in the manufacturing, education, and health sectors. The authors validated their survey tool by collecting data from 732 firms operating in Germany, France, UK and US. In the construction industry, management practices questionnaires have been developed by the Construction Industry Institute (CII) through the collaboration of researchers and industry practitioners. The tool has been validated by collecting data from various projects in North America. This research uses CII Survey Tool (Appendix-1B2) after conducting validation by discussing with local experts, and collecting productivity data from various building projects.

Construction projects' productivity can be expressed in either absolute or relative terms. In absolute term, the units of measure of both output and input are shown in the productivity value. The relative measure or Productivity Factor $(\mathrm{PF})$ refers to the ratio of actual to planned productivity. Actual productivity is computed using project value as output and actual completion time as input. Planned productivity is calculated using project value as output and planned time as input. Productivity factor (PF) is a more useful measure to compare the productivity of different construction projects than the absolute measure (Nasir, 2013).Thus; $\mathrm{PF}$ is used in this research.

\section{Data collection}

This study was conducted in two phases. In phase 1, qualitative data was collected using indepth interviews that took an average of one and half hours. The objective of this stage was to identify the best practices for construction methods using knowledge and experience of local construction experts. Nineteen professionals who have been working with the prequalified principal contractors in Victoria, Australia and having experience ranging from five to forty years were interviewed (Table 1). The experts have been working as general manager, construction manager, project manager, project coordinator, project engineer, site engineer, contract administrator, supervisor and cost manager. Snowballing technique was used to select the participants for interviews. Moreover, the experts were selected based on their experience in working with exemplar contractors. The exemplars were principal contractors that had the capacity to deliver numerous projects within a fiscal year. They were chosen based on the companies information provided in May 2015, IBIS World Report. Semi-structured questions were prepared for the interview. The questions included: Does this practice exist? How is it practiced by local contractors? Is this practice best for improving the productivity of building projects? What other practices enhance the productivity of building projects? The interviews 
were conducted until the data analysis reached saturation point. Saturation refers to the point where similar reasons for accepting or rejecting a particular best practice were given by the participants.

Table 1: Interviewees' years of experience in construction industry

\begin{tabular}{|ll|}
\hline Experience & Number \\
\hline $0-5$ & 0 \\
\hline $5-10$ & 6 \\
\hline $10-15$ & 5 \\
\hline $15-20$ & 2 \\
\hline $20+$ & 6 \\
\hline Total & $\mathbf{1 9}$ \\
\hline
\end{tabular}

In phase 2, an industry-wide questionnaire survey was conducted (Appendix-1). The objective of this stage was to prioritize best practices for construction methods; develop a scoring tool and a logistic regression model. Thirty-nine pre-qualified principal contractors, based on their managerial capability, financial capacity, expertise and experience, were selected as the units of analysis (Department of Treasury and Finance, 2015). Victorian construction industry is comprised of a few principal contractors, all of whom were considered in this study. After identification of the unit of analysis, professionals who have been involved in the construction of building projects were contacted to respond to the questionnaires. General Managers, construction directors, construction managers and project managers, project coordinators and site managers with an average of fifteen years of experience participated in the survey that was administered using face-to-face interviews in which the researchers clarified the questions and took notes. The experts were asked to rate the relative importance of each element in improving productivity of building construction projects based on their experience in the industry using a 1 to 5 response scale(Appendix-1A). Moreover, they were requested to indicate the level of implementation of the best practices for construction methods on a particular building project that had been completed within the previous five years (Appendix-1B).

Mixed methods were used in this study. Since management practices could vary from country to country and from project to project, interviews were used to investigate the context-specific best practices during Phase I. A constructivist paradigm was adopted during stage I as there is no single best management practice. Different construction industries have their own best practices and no single best practice exists. Thus, context-specific best practices for construction methods should be investigated prior to conducting industry-wide questionnaire survey and analysing data objectively. This aspect of the research makes it different from previous similar studies that entirely used a positivist paradigm.

\section{Data analysis}

Qualitative data analysis consists of three concurrent flows of activity: data reduction, data display, and conclusion drawing (Rose, Spinks and Canhoto, 2015). Data reduction is a form of analysis that sharpens sorts, focuses, discards, and organizes data in a way that final conclusions can be drawn (Miles and Huberman, 1994). Writing summaries, coding, and making clusters are common methods used in data reduction process. The latter two methods are more suitable when the research is entirely inductive in nature. In this study, writing summaries was used as a technique to reduce the transcribed interviews. The reduced data is displayed using matrices, graphs, charts and networks. In this research, matrix technique is used as it is suitable to display the summaries of the responses in matrix boxes. Once the data is displayed, the conclusion is drawn by either noticing the patterns of similarities and differences between categories and/or processes, clustering, making contrasts and comparisons and noting relations between concepts (Rose, Spinks and Canhoto, 2015). The latter three strategies for conclusion drawing are more appropriate if the study is entirely qualitative in nature. Qualitative data was analysed and used 
as input to the quantitative phase in this research context. Identifying the pattern of similarity between the responses was used to draw a conclusion.

To analyse the data collected during phase I, the audiotaped interviews were first transcribed, and a matrix was prepared in Excel spreadsheet to match the responses of an expert and management practices. A summary of each interview result was written in a matrix box and conclusion was drawn for each practice. Similar iterative procedures were used for all the interview results. The similarity between the successive summaries was observed to find saturation point. After analysing the outcome of the fifteenth interview, similar explanations for management practices was observed. Although the saturation point was reached at the fifteenth interviewee, more interviews were conducted until the nineteenth participant, for the sake of confirmation. Finally, the best practices that were described as applicable to building projects by all participants were included in the list for the industry-wide survey.

To prioritize the best practices, Relative Importance Index (RII) was computed by using the equation below, and weights were assigned to the best practices (Enshassi et al., 2007). Furthermore, Friedman's and Wilcoxon's tests were conducted to check whether there were significant differences among the best practices.

$$
\mathrm{RII}=\frac{\left.5\left(\mathrm{n}_{5}\right)+4\left(\mathrm{n}_{4}\right)+3\left(\mathrm{n}_{3}\right)+2\left(\mathrm{n}_{2}\right)+\mathrm{n}_{1}\right) * 100}{5\left(\mathrm{n}_{1}+\mathrm{n}_{2}+\mathrm{n}_{3}+\mathrm{n}_{4}+\mathrm{n}_{5}\right)}
$$

The number of respondents who selected 1 for not important, 2 for slightly important, 3 for somewhat important, 4 for very important, and 5 for extremely important practice to improve productivity in building projects are shown as $\mathrm{n}_{1}, \mathrm{n}_{2}, \mathrm{n}_{3}, \mathrm{n}_{4}$, and $\mathrm{n}_{5}$ respectively.

To develop a scoring tool for the best practices, the weight of each practice was distributed proportionally from Level B to Level F, and Level A was assigned 0 . The results are shown in the Findings and Discussion section, and Appendix-2. One-way ANOVA test was conducted to check if there was a significant difference between projects having higher score and lower score, and to validate the tool used to measure the best practices. Correlation analysis was conducted to check the relationship among best practices for construction methods, project delays, project costs, company size, experience of construction firms and annual turnover.

Logistic regression analysis was conducted to develop a model, to predict probability with respect to baseline productivity factor, based on a project's construction methods score. The model was validated by dividing the data obtained from 39 companies randomly into two (Zayed and Halpin, 2005). Thirty-one data points were used to build a model and the remaining data sets were used for validation purpose. The rule of thumb for sample size for logistic regression analysis states that the number of "Events Per Variable (EPV)" should be greater than 10 (Peduzzi et al., 1996). Some authors argue that the minimum of 10 events per predictor is conservative (Vittinghoff and McCulloch, 2007). In this research context, there were 18 projects with productivity factors greater than baseline $\mathrm{PF}=0.97$ (positive events) and there is one predictor (construction methods). EPV $=18>10$ and logistic regression analysis can be conducted. Moreover, to increase the reliability of the model, bootstrapping was conducted. Before developing the final model, six alternative models were developed by varying the baseline PF. Using validation datasets, probabilities were predicted, Receiver Operating Characteristic (ROC) curves were drawn and Area under Curve (AUC) was computed.

\section{Findings and discussion}

\section{Identification of best practices for construction methods in building projects}

Ten best practices for construction methods were identified. These are integrated schedule, work schedule strategies, schedule execution and management, dynamic site layout plan, traffic 
control plan, site security plan, machinery positioning strategy, project start-up plan, project completion plan, and innovations and new technologies. For the sake of brevity, a summary of the findings of only two best practices is indicated in Table 2 .

Construction schedule that integrates work, materials procurement and delivery, machinery, sub-contractors, financial and other schedules have positive impact on the productivity of building projects. If work schedule is integrated with material and machinery schedules then the project teams are aware of when a particular activity needs to be done, what type of machinery should be hired, how much material and manpower should be deployed, and thus track the delivery of materials. The research participants described that the best-performing principal contractors link all the schedules together.

Developing a suitable working-hours strategy is also found to be another important management practice that increases productivity. There are working hour restrictions imposed by city councils, and contractors are required to develop a strategy to reduce project delays. Most commercial contractors in Victoria follow the calendar prepared by Construction, Forestry, Mining and Energy Union, which is typically 36 working hours per week. They schedule to work either four, five or six days a week and sign contracts with their subcontractors accordingly. Some respondents described that on Saturdays they reduce the working hours to $50 \%$. They described that most workers are not productive on Saturday, Sunday, and rostered days off. Moreover, the participants indicated that it is expensive to work on Sundays and after hours, as the rates provided in the Enterprise Bargaining Agreement are high.

Table 2: Summary of interview results

\begin{tabular}{|ll|}
$\begin{array}{l}\text { Construction } \\
\text { Methods }\end{array}$ & \multicolumn{1}{c|}{ Summary } \\
\hline $\begin{array}{l}\text { Integrated } \\
\text { schedule }\end{array}$ & $\begin{array}{l}\text { Linking various programs together is essential. Most principal contractors try to link } \\
\text { materials procurement, lead time, work status, main work program and other issues such } \\
\text { as the schedule for FFE (Fittings, Fixture, and Equipment) together. }\end{array}$ \\
\hline $\begin{array}{l}\text { Dynamic site } \\
\text { layout plan }\end{array}$ & $\begin{array}{l}\text { The site plan is constantly changing for the sake of productivity. The gates in and out, for } \\
\text { instance, might be changed throughout the construction period. They could be changed } \\
\text { after completion of excavation, during superstructure and landscaping works. The site } \\
\text { layout is also planned by considering materials delivery and the requirement of temporary } \\
\text { facilities at various stages of the project. }\end{array}$ \\
\hline
\end{tabular}

Changing a site plan based on phases of a construction project also improves productivity. The interviewees described that although the practice of adopting dynamic site layout is important, it should be planned ahead to be effective. They indicated that experienced contractors include their site logistics plan in a tender document. The changes in a plan that is based on the stages of construction are clearly shown in the tender document so that sub-contractors are aware of the future changes in the site layout. Moreover, the respondents described that integration of traffic control and site layout plans is of paramount importance in reducing the loss of productivity.

Construction machinery positioning strategy is also an important practice that influences productivity in the construction of building projects. The critical machine for these projects is a tower crane and its location on a site is planned by considering the weight to be loaded, distance from the street from which materials are lifted, the area of a building under construction and distance from existing buildings. The respondents described that careful analysis of the position of a crane using either $2 \mathrm{D}$ drawings or $3 \mathrm{D}$ models is an important practice. 


\section{Relative importance of the best practices for construction methods}

Based on the results of RII analysis, the five most critical practices that have the potential to improve the productivity in building projects (Table 3) are traffic control plan, project start-up plan, machinery positioning strategy, project completion plan, and dynamic site layout plan. The finding of this study confirmed that best practices that are given top priority in other project types cannot directly be used for building projects. Traffic control plan was found to be the most significant practice that could enhance the productivity of building projects. However, for infrastructure projects the practice is not given top priority, and for the industrial projects traffic control plan is not included in the list of best practices (CII, 2013a; b). In Victoria, regulations oblige contractors that use public roads during construction periods, to prepare traffic management plans. Failure to prepare such plans will result in financial penalty and could lead to suspension of works if accidents occur. According to Road Safety (Traffic Management) Regulations (2009), any person conducting an activity on a road or road related areas must maintain a copy of the traffic management plan on the worksite at all times when the work is undertaken, and it should be available for inspection on request by an authorized person. The absence of the plan is an offense against the Regulation. Therefore, to reduce project delay and related penalty, principal contractors considered traffic control planning as the most important practice.

Project start-up planning is also considered among crucial practices that should be given priority in building projects. The finding of this study suggests that principal contractors in Victoria, Australia attempt to reduce the initial project delay by using a project start-up plan which could be used as a checklist to remind the project team regarding the information that is required to commence a project. In the plan, the pre-commencement meeting dates, resource requirements, and any other information which could be forgotten during commencement date are included. As per the plan, the principal contractor conducts meetings with its subcontractors and resolves matters such as interference among subcontractors which could be one of the causes of the delays during project start-up.

Table 3: Relative importance of the best practices

\begin{tabular}{|lcc|}
\hline \multicolumn{1}{c}{ Elements } & Weight (\%) & Rank \\
\hline Traffic control plan & 86 & 1 \\
\hline Project start-up plan & 86 & 1 \\
\hline Machinery positioning strategy & 83 & 3 \\
\hline Project completion plan & 82 & 4 \\
\hline Dynamic site layout plan & 82 & 5 \\
\hline Schedule execution and management & 77 & 6 \\
\hline Work schedule strategies & 73 & 7 \\
\hline Site security plan & 73 & 7 \\
\hline Integrated schedule & 66 & 9 \\
\hline Innovations and new technologies & 64 & 10 \\
\hline
\end{tabular}

Similarly, machinery positioning strategy is considered to be the most significant practice for building projects. However, the practice is rated as having less importance for infrastructure projects and as an intermediate significance for industrial projects. Since the critical machinery for high-rise building projects is a tower crane, its location should be carefully analysed for the sake of productivity. The construction systems in Victoria, such as the use of heavy precast concrete panels in building projects, could influence the location of cranes. If the machine is not positioned in a suitable location, these concrete elements could not be placed in accordance with the scheduled time. The contractor might change the design of the panels to reduce their weights or look for other alternatives to place them. Moreover, since most multi-story building projects are in the city of Melbourne where there are restricted spaces, machinery positioning strategy is the crucial practice to improve productivity. 
In Table 4, the results of Friedman test are presented. As the p-value $(<0.001)$ is much less than 0.05 , the null hypothesis which states the mean of all the best practices is equal should be rejected. Therefore, there is a statistically significant difference between the best practices. To identify where such difference lies, Wilcoxon Test was conducted.

Table 4: Outputs of the Friedman test

\begin{tabular}{|c|c|}
\hline Elements & Mean Rank \\
\hline Integrated Schedule & 3.72 \\
\hline Work Schedule Strategies & 4.76 \\
\hline Schedule Execution and Management & 5.49 \\
\hline Dynamic Site Layout Plan & 6.24 \\
\hline Traffic Control Plan & 6.76 \\
\hline Site Security Plan & 4.86 \\
\hline Machinery and Equipment Positioning & 6.29 \\
\hline Project start-up plan & 6.82 \\
\hline Project Completion Plan & 6.59 \\
\hline Innovations and New Technologies & 3.47 \\
\hline df & 9 \\
\hline$\chi^{2}$ approximation & 74.73 \\
\hline $\mathrm{p}$-value & $<0.001$ \\
\hline
\end{tabular}

The results of Wilcoxon test are shown in Table 5. Accordingly, from forty-five possible combinations, statistically significant differences exist among twenty-nine of them (Table 5). Ten possible combinations among the top five best practices were found to be statistically insignificant at the 5\% significance level. This shows that there is no major difference among the top five best practices. Therefore, traffic control plan, project start-up plan, machinery positioning strategy, project completion plan and dynamic site layout plan are equally important to improve productivity in building projects.

Table 5: P-values obtained using Wilcoxon analysis

\begin{tabular}{|c|c|c|c|c|c|c|c|c|c|}
\hline IS & WSS & SEM & DSLP & TCP & SSP & MPS & PSP & PCP & INT \\
\hline IS & .013 & .001 & $<.001$ & $<.001$ & .040 & $<.001$ & $<.001$ & $<.001$ & .557 \\
\hline WSS & & .046 & .014 & $<.001$ & 1.00 & .028 & .002 & .013 & .003 \\
\hline SEM & & & .242 & .023 & .158 & .252 & .036 & .140 & $<.001$ \\
\hline DSLP & & & & .159 & .009 & .950 & .162 & .947 & $<.001$ \\
\hline TCP & & & & & .001 & .233 & .917 & .414 & $<.001$ \\
\hline SSP & & & & & & .023 & .002 & .025 & .004 \\
\hline MPS & & & & & & & .339 & .836 & $<.001$ \\
\hline PSP & & & & & & & & .446 & $<.001$ \\
\hline PCP & & & & & & & & & $<.001$ \\
\hline INT & & & & & & & & & \\
\hline
\end{tabular}

Legend: IS=Integrated Schedule, WSS $=$ Work Schedule Strategies, SEM=Schedule Execution and Management, DSLP= Dynamic Site Layout Plan, TCP=Traffic Control Plan, SSP=Site Security Plan, MPS=Machinery Positioning Strategy, $\mathrm{PSP}=$ Project Start-up Plan, PCP= Project Completion Plan, INT=Innovation and new Technologies.

\section{Best practices for construction methods scoring tool and validation}

To develop the Scoring Tool (Appendix-2) for best practices, the weight obtained using RII analysis was proportionally distributed. For instance, the weight for the practice integrated schedule is 0.66 , and the proportions are Level $\mathrm{A}=0$; Level $\mathrm{B}=1 / 5^{*}(0.66)=0.13$; Level $\mathrm{C}=2 / 5^{*}(0.66)=0.26$; Level $\mathrm{D}=3 / 5^{*}(0.66)=0.40$; Level $\mathrm{E}=4 / 5^{*}(0.66)=0.53$; and Level $\mathrm{F}=0.66$ (Table 6). Similarly, the scoring tools for other best practices were developed. In Table 6 , the score of the practice "integrated schedule" for one of the projects is shown in the last column. Since the respondent of that particular project ticked Level C, the equivalent score for 
"integrated schedule" is 0.26 . The total construction methods score for a project is computed by adding the scores of the ten best practices. All the thirty-nine survey data was converted to scores of the best practices for construction methods. Overall there are 390 (39*10) best practices scores.

Table 6: Integrated schedule score

\begin{tabular}{|clc|}
\multicolumn{5}{|c|}{ Survey Data Collected using Standard Tool (CII, 2013b) } & $\begin{array}{c}\text { Distributed } \\
\text { Weights }\end{array}$ \\
\hline Level & The use of an integrated schedule using CPM is not applicable. & 0 \\
\hline Level & The use of an integrated schedule using CPM has not been addressed & 0.13 \\
\hline Level C & $\begin{array}{l}\text { Developing a schedule with no resources present and managing schedule status } \\
\text { via duration or remaining duration but no link to earned percent complete } \\
\text { progress from associated deliverables per activity. }\end{array}$ & 0.26 \\
\hline Level & $\begin{array}{l}\text { Developing a schedule with resources present but no link to earned percent } \\
\text { complete progress from associated deliverables per activity. }\end{array}$ & 0.40 \\
\hline Level E & $\begin{array}{l}\text { Developing a schedule with resources present but no link to earned percent } \\
\text { complete progress from associated deliverables per activity. Resources are updated } \\
\text { to reflect current work content or quantity adjustments. }\end{array}$ & 0.53 \\
\hline Level F & $\begin{array}{l}\text { Continuation of Level E and updated to include quantity adjustments. Earned } \\
\text { progress for the activity is based on measured or assessed work completed per } \\
\text { deliverables per activity. Progress measurement performed in application adapted } \\
\text { specifically for each deliverable. }\end{array}$ & 0.66 \\
\hline
\end{tabular}

One-way ANOVA was conducted, to test the hypothesis that building projects with higher scores of the best practices for construction methods have also higher productivity. The projects were grouped based on the baseline mean score of 4.84. Projects with scores less than the mean value were classified under Group 1(low score) and those having scores greater than the baseline were classified under Group 2 (high score). In Table 7, the descriptive statistics and ANOVA results are presented. The mean productivity factor of Group 1 and Group 2 are 0.88 and 1.01 respectively. The p-value (0.004) is less than 0.05 indicating that there is statistically significant difference between the two groups. The finding implies that building projects with a higher level of implementation of the best practices for construction methods also have higher productivity. Therefore, the tool developed to measure the best practices is valid. The tool is shown in Appendix-2.

Table 7: One-way ANOVA for PF and construction methods score

\begin{tabular}{|c|c|c|c|c|c|c|c|c|c|c|}
\hline \multicolumn{5}{|c|}{ Descriptive } & \multicolumn{6}{|c|}{ ANOVA } \\
\hline & \multirow[b]{2}{*}{$\mathrm{N}$} & \multirow[b]{2}{*}{ Mean } & \multicolumn{2}{|c|}{ 95\% CI for Mean } & & \multirow[b]{2}{*}{$\begin{array}{l}\text { Sum of } \\
\text { Squares }\end{array}$} & \multirow[b]{2}{*}{ df. } & \multirow[b]{2}{*}{ Mean Square } & \multirow[b]{2}{*}{$\mathrm{F}$} & \multirow[b]{2}{*}{ Sig. } \\
\hline & & & $\begin{array}{l}\text { Lower } \\
\text { Bound }\end{array}$ & $\begin{array}{l}\text { Upper } \\
\text { Bound }\end{array}$ & & & & & & \\
\hline Group 1 & 18 & 0.882 & 0.808 & 0.955 & Between Groups & 0.161 & 1 & 0.161 & 9.643 & 0.004 \\
\hline Group 2 & 21 & 1.012 & 0.960 & 1.061 & Within Groups & 0.617 & 37 & 0.017 & & \\
\hline Total & 39 & 0.951 & 0.905 & 0.998 & Total & 0.777 & 38 & & & \\
\hline
\end{tabular}

\section{Relationship between project delay and best practices}

Correlation analysis was conducted to investigate the relation between project delay and the best practices and the results are indicated in Table 8 . There is statistically significant negative correlation between integrated schedule, machinery positioning strategy, project start-up plan, project completion plan, and project delay. The results show that high levels of implementation of the best practices are associated with low project delay.

Correlation analysis was also conducted to check if implementation levels of the best practices vary based on project cost, annual turnover of companies, experience of companies, and company sizes. The results of the analysis are shown in Table 9. Statistically significant 
correlation between project cost and construction methods $(\mathrm{p}=0.001<0.05)$ was found. Thus, one of the main reasons for variations in the level of implementation of the best practices could be the change in project costs. As the project costs increase due to increment in the scope of works, the levels of implementation also increase. Although there is a positive correlation between construction methods and annual turnover, experience, and company size, the p-values are not statistically significant. This shows that larger and experienced companies may not fully implement the best practices if the scope of a project is small.

Table 8: Spearman correlation coefficients for project delay

\begin{tabular}{|cccccccccccccc|} 
& & PF & IS & WSS & SEM & DSLP & TCP & SSP & MPS & PSP & PCP & INT & CM \\
\hline \multirow{2}{*}{ Delay } & Coeff. & -.940 & -.470 & -.204 & -.195 & -.262 & -.177 & -.011 & -.349 & -.524 & -.366 & -.079 & -.425 \\
\cline { 2 - 12 } & Sig. & $<.001$ & .003 & .213 & .234 & .107 & .280 & .949 & .030 & .001 & .022 & .635 & .007 \\
\hline
\end{tabular}

Legend: PF= Productivity Factor, IS=Integrated Schedule, WSS = Work Schedule Strategies, SEM=Schedule Execution and Management, DSLP $=$ Dynamic Site Layout Plan, TCP=Traffic Control Plan, SSP=Site Security Plan, MPS=Machinery Positioning Strategy, PSP=Project Start-up Plan, PCP = Project Completion Plan, INT=Innovation and new Technologies, $\mathrm{CM}=$ Construction Methods.

Table 9: Spearman correlation coefficients of company profile and project cost

\begin{tabular}{|c|c|c|c|c|c|c|}
\hline & & $\begin{array}{l}\text { Construction } \\
\text { Methods }\end{array}$ & $\begin{array}{l}\text { Annual } \\
\text { Turnover }\end{array}$ & $\begin{array}{l}\text { Company } \\
\text { Experience }\end{array}$ & $\begin{array}{l}\text { Company } \\
\text { Size }\end{array}$ & $\begin{array}{l}\text { Project } \\
\text { Cost }\end{array}$ \\
\hline \multirow[t]{2}{*}{ Annual Turnover } & Coeff. & 0.119 & & & & \\
\hline & Sig. & 0.570 & & & & \\
\hline \multirow{2}{*}{$\begin{array}{l}\text { Company } \\
\text { Experience }\end{array}$} & Coeff. & 0.224 & 0.062 & & & \\
\hline & Sig. & 0.176 & 0.769 & & & \\
\hline \multirow[t]{2}{*}{ Company Size } & Coeff. & 0.261 & & 0.520 & & \\
\hline & Sig. & 0.109 & & 0.001 & & \\
\hline \multirow[t]{2}{*}{ Project Cost } & Coeff. & 0.538 & 0.356 & 0.547 & 0.488 & 1.00 \\
\hline & Sig. & 0.001 & 0.081 & 0.001 & 0.002 & \\
\hline
\end{tabular}

\section{Logistic regression model building and validation}

Binary logistic regression model was developed to predict the probability of exceeding the baseline productivity factor of 0.97 which is the mean PF value. Some of the results are shown in Table 10. For the sake of brevity all the outputs are not presented in this paper. The model's Omnibus Test indicates significance value of $0.016<0.05$; Hosmer and Lemeshow Test shows a p-value of $0.172>0.05$ indicating the strength of the model. Furthermore, the model's overall pvalue is $0.029<0.050$ and it is acceptable. The model in Block- 0 during the analysis indicates the predictive capacity of $58.1 \%$ whereas the final model has a predictive capacity of $74.2 \%$. Thus, the selected model is good. Moreover, the coefficient of the variable after bootstrapping using 1000 samples is statistically significant $(\mathrm{p}=0.01<0.05)$.

Using the coefficients indicated in Table 10, the final model is $\log (\mathrm{p} / 1-\mathrm{p})=0.749 * \mathrm{CM}-3.366$. To compute probabilities, the model's equation is simplified as follows. Let $\mathrm{L}=\mathrm{B}_{\mathrm{o}}+\mathrm{B}_{1}{ }^{*} \mathrm{CM}$, then $\mathrm{P}=\mathrm{e}^{\mathrm{L}} /\left(1+\mathrm{e}^{\mathrm{L}}\right)$. By using this formula, probabilities are predicted and the sigmoid graph is drawn as shown in Figure 1. Users can compute their projects' CM score using the scoring technique (Appendix-2) developed in this research and read the probability from the graph. For instance, if a project manager computes the construction methods score of 4.0 then the probability that a project's PF exceeding 0.97 is $40 \%$. Thus, the actual productivity could be less than planned productivity and the possibility of occurrence of project delay is high. However, the project manager can increase the chance of completing a project on or before the contract date by increasing the level of implementation of the best practices. The tools developed in this study have paramount significance for assisting building project teams to carry out such predictions. 
The model was validated by predicting the probabilities of the validation datasets. Receiver Operating Characteristic (ROC) Curve was drawn (Figure 2) and Area under the Curve (AUC) was computed to be 0.833 . Thus, the model is valid as AUC is greater than 0.5 and close to 1.0.

Table 10: Summary of the outputs from logistic regression analysis

\begin{tabular}{|c|c|c|c|c|c|c|c|c|}
\hline \multicolumn{9}{|c|}{ Variables in the Equation } \\
\hline & \multirow[t]{2}{*}{ B } & \multirow[t]{2}{*}{ S.E. } & \multirow[t]{2}{*}{ Wald } & \multirow[t]{2}{*}{ df } & \multirow[t]{2}{*}{ Sig. } & \multirow[t]{2}{*}{$\operatorname{Exp}(B)$} & \multicolumn{2}{|c|}{ 95\% C.I.for EXP(B) } \\
\hline & & & & & & & Lower & Upper \\
\hline Construction Methods (CM) & 0.749 & 0.343 & 4.785 & 1 & 0.029 & 2.116 & 1.081 & 4.141 \\
\hline Constant & -3.366 & 1.724 & 3.809 & 1 & 0.050 & 0.035 & & \\
\hline \multicolumn{9}{|c|}{ Bootstrap for Variables in the Equation } \\
\hline & & & & & \multicolumn{4}{|c|}{ Bootstrap } \\
\hline & \multirow[t]{2}{*}{ B } & \multirow[t]{2}{*}{ Bias } & \multirow[t]{2}{*}{ S.E } & \multirow[t]{2}{*}{ Sig. } & \multicolumn{4}{|c|}{$95 \%$ Confidence Interval } \\
\hline & & & & & \multicolumn{2}{|l|}{ Lower } & \multicolumn{2}{|l|}{ Upper } \\
\hline Construction Methods (CM) & 0.749 & 0.120 & 0.465 & 0.013 & \multicolumn{2}{|l|}{0.156} & \multicolumn{2}{|l|}{1.995} \\
\hline Constant & -3.366 & -0.548 & 2.243 & 0.031 & \multicolumn{2}{|l|}{-9.286} & \multicolumn{2}{|l|}{-0.448} \\
\hline \multicolumn{9}{|c|}{ Classification Table } \\
\hline \multirow{2}{*}{\multicolumn{2}{|c|}{ Observed }} & \multicolumn{3}{|c|}{ Predicted } & & & & \\
\hline & & \multicolumn{2}{|c|}{ PF } & \multicolumn{3}{|c|}{ Percentage Correct } & & \\
\hline \multirow{3}{*}{$\mathrm{PF}$} & 0 & 0 & 1 & & & & & \\
\hline & 1 & 8 & 5 & & & & & \\
\hline & & 3 & 15 & & & & & \\
\hline
\end{tabular}

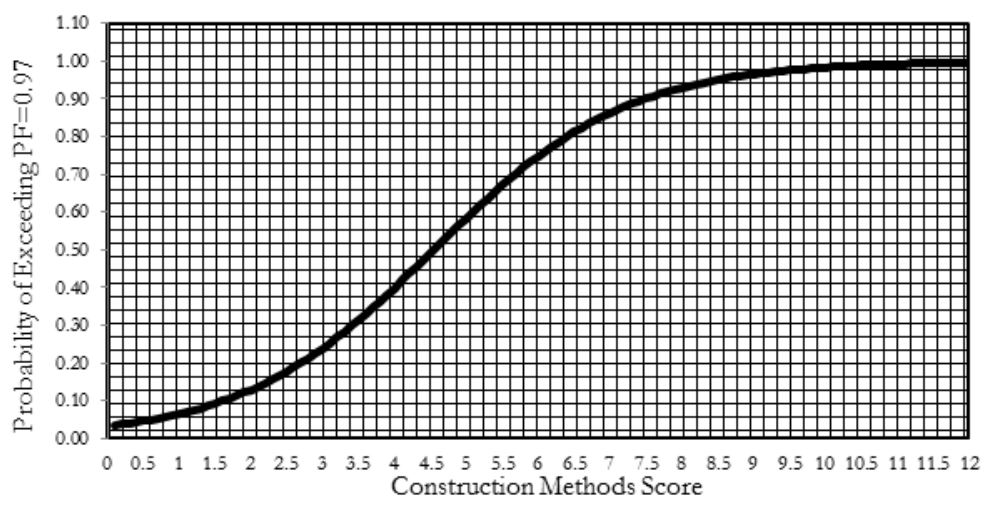

Figure 1: Probability plot of construction methods

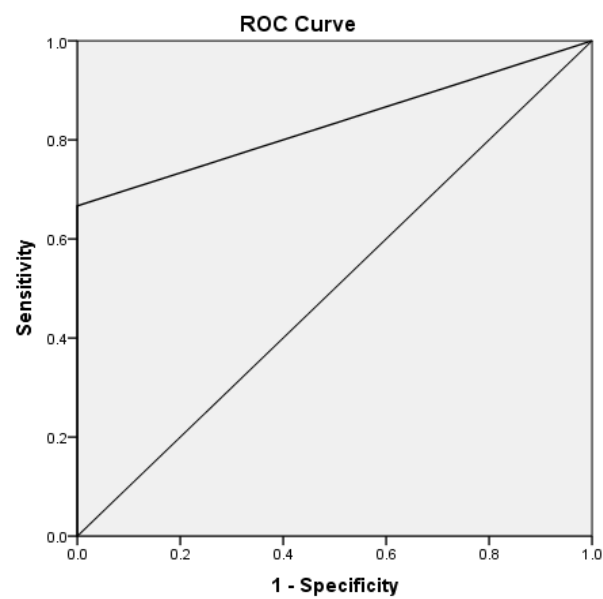

Figure 2: ROC curve 


\section{Conclusion}

Ten best practices for construction methods were identified and prioritized for building projects in Victoria, Australia. Among the ten best practices, traffic control plan, project startup plan, machinery positioning strategy, project completion plan, and dynamic site layout plan were found to be the top five most important best practices. The study revealed that high levels of implementation of best practices are associated with low project delays. The levels of implementation of best practices increase as project costs increase. Positive correlation between company's annual turnover, company size, company experience, and best practices were found. However, these relationships are not statistically significant. Logistic regression model was developed to predict probability based on the best practices score.

This study has implications for both contractors and future researchers. The principal contractors involved in the construction of building projects in Victoria, Australia can implement the identified best practices to improve the productivity of their projects. They can also score the construction methods and use the logistic regression model to predict the probability of exceeding a baseline productivity factor. Based on the predicted productivity, contractors can implement corrective actions to achieve the desired level of productivity. Contractors in other countries can also use these practices to enhance the productivity of their building projects, but the best practices should be adapted to local context as they could vary from country to country. Furthermore, sub-contractors both in Australia and other countries might not enhance their building projects' productivity by implementing the identified best practices as this study focuses on the management practices of principal contractors only. Future researchers can use this study as a background to investigate best practices for construction methods that could enhance construction productivity from sub-contractors' perspectives. Furthermore, researchers in other countries can also use the best practices identified in this research to validate their suitability in a particular environment and to identify the most critical practices.

\section{References}

Arditi, D. and Mochtar, K., 1996. Productivity improvement in the Indonesian construction industry. Construction Management and Economics, 14(1), pp.13-24. doi: http://dx.doi.org/10.1080/01446199600000003

Attalla, M.M., 1997. Project Control Techniques: Reconstruction of Occupied Buildings. MSc Thesis, University of Waterloo, Canada.

Australian Bureau of Statistics, 2013. Private Sector Construction Industry, Australia, 2011-12. Cat. no.8772.0. Canberra.

Australian Bureau of Statistics, 2016. Counts of Australian Businesses, including Entries and Exits, Jun 2011 to Jun 2015. Cat. no.8165.0. Canberra.

Bell, L.C. and Stukhart, G., 1987. Costs and benefits of materials management systems. Journal of Construction Engineering and Management, 113(2), pp.222-34. doi: http://dx.doi.org/10.1061/(ASCE)07339364(1987)113:2(222)

Bloom, N. and Van Reenen, J., 2007. Measuring and explaining management practices across firms and countries. Quarterly Journal of Economics, 122(4), pp.1351-408. doi: http://dx.doi.org/10.1162/qjec.2007.122.4.1351

Caldas, C.H., Kim, J.-Y., Haas, C.T., Goodrum, P.M. and Zhang, D., 2014. Method to Assess the Level of Implementation of Productivity Practices on Industrial Projects. Journal of Construction Engineering and Management, 141(1), p.04014061.

CFMEU, 2016. 2016 Interim RDO calendar [online]. Available at: https://vic.cfmeu.org.au.

Choi, C. and Harris, F., 1992. A model for Determining Optimum Crane Position: Thomas Telford Services Ltd Thomas Telford House, 1 Heron Quay, London, England 503-4.

CII, 2013a. Best Productivity Practices Implementation Index for Industrial Projects. Austin, Texas.

CII, 2013b. Best Productivity Practices Implementation Index for Infrastructure Projects. Austin, Texas.

CII, 2016. Construction Industry Best Practices [online]. Available at: https://www.construction-institute.org.

Dai, J., Goodrum, P.M., Maloney, W.F. and Srinivasan, C., 2009. Latent Structures of the Factors Affecting Construction Labor Productivity. Journal of Construction Engineering \& Management, 135(5), pp.397-406. doi: http://dx.doi.org/10.1061/(ASCE)0733-9364(2009)135:5(397) 
Department of Treasury and Finance, 2015. Construction Supplier Register [online] Victoria, Australia. Available at: http://www.dtf.vic.gov.au.

Enshassi, A., Mohamed, S., Mustafa, Z.A. and Mayer, P.E., 2007. Factors affecting labour productivity in building projects in the Gaza Strip. Journal of Civil Engineering and Management, 13(4), pp.245-54.

EPA, 2016. Noise in commercial construction sites and large residential and mixed-use developments [online]. Available at: http://www.epa.vic.gov.au.

Fair Work Commission, 2016. Building and Construction General On-site Award 2010 [online]. Available at: https://www.fwc.gov.au/.

Fangel, M., 1984. Planning project start-up. International Journal of Project Management, 2(4), pp.242-5. doi: http://dx.doi.org/10.1016/0263-7863(84)90043-7

Hanna, A.S., Chang, C.-K., Sullivan, K.T. and Lackney, J.A., 2008. Impact of shift work on labor productivity for labor intensive contractor. Journal of construction engineering and management, 134(3), pp.197-204. doi: http://dx.doi.org/10.1061/(ASCE)0733-9364(2008)134:3(197)

Hewage, K.N., Gannoruwa, A. and Ruwanpura, J.Y., 2011. Current Status of Factors Leading to Team Performance of On-Site Construction Professionals in Alberta Building Construction Projects. Canadian Journal of Civil Engineering, 38(6), pp.679-89. doi: http://dx.doi.org/10.1139/111-038

Hinze, J. and Wilson, G., 2000. Moving toward a zero injury objective. Journal of Construction Engineering and Management, 126(5), pp.399-403. doi:http://dx.doi.org/10.1061/(ASCE)0733-9364(2000)126:5(399)

Jarkas, A.M. and Bitar, C.G., 2011. Factors affecting construction labor productivity in Kuwait. Journal of Construction Engineering and Management.

Kerzner, H., 2010. Project Management-Best Practices: Achieving Global Excellence: John Wiley and Sons.

Lam, P.T., Wong, F.W. and Chan, A.P., 2006. Contributions of designers to improving buildability and constructability. Design Studies, 27(4), pp.457-79. doi: http://dx.doi.org/10.1016/j.destud.2005.10.003

Miles, M.B. and Huberman, A.M., 1994. Qualitative data analysis: An expanded sourcebook: SAGE Publications.

Nasir, H., 2013. Best Productivity Practices Implementation Index (BPPII) for Infrastructure Projects. Doctoral Dissertation, University of Waterloo.

Peduzzi, P., Concato, J., Kemper, E., Holford, T.R. and Feinstein, A.R., 1996. A simulation study of the number of events per variable in logistic regression analysis. Journal of clinical epidemiology, 49(12), pp.1373-9. doi: http://dx.doi.org/10.1016/S0895-4356(96)00236-3

PMI, 2013. A Guide to the Project Management Body of Knowledge (PMBOK Guide)_Fifth Edition. Pennsylvania, USA.

PrefabAUS, 2014. Prefabricating Australia: Growing Our Off-site Construction Sector. In: PrefabAUS 2014 Inaugural Conference Melbourne, Australia, 11-13 August.

Rose, S., Spinks, N. and Canhoto, A.I., 2015. Management research : applying the principles: Abingdon, Oxon ; New York : Routledge, 2015.

Safe Work Australia, 2014. Traffic Management: Guide for Construction Work [online] Canberra, Australia. Available at: http://www.safeworkaustralia.gov.au.

Stewart, L., 2002. Why rent? For low-use machines. Construction Equipment, 105(7), p.50.

Tommelein, I. and Zouein, P., 1993. Interactive dynamic layout planning. Journal of construction engineering and management, 119 (2), pp.266-87. doi: http://dx.doi.org/10.1061/(ASCE) 0733-9364(1993)119:2(266)

Vittinghoff, E. and McCulloch, C.E., 2007. Relaxing the rule of ten events per variable in logistic and Cox regression. American journal of epidemiology, 165(6), pp.710-18. doi: http://dx.doi.org/10.1093/aje/kwk052

Wheeldon, D., 2012. Why building materials imports are on the rise in Australia? Infolink Architecture and Design. Melbourne, Australia.

Zayed, T.M. and Halpin, D.W., 2005. Productivity and cost regression models for pile construction. Journal of Construction Engineering and Management, 131(7), pp.779-89. doi: http://dx.doi.org/10.1061/(ASCE)0733$\underline{9364(2005) 131: 7(779)}$ 


\section{Appendix-1}

\section{Questionnaire}

\section{A. Relative Importance of the Management Practices for Construction Methods}

Please rate the following elements based on their degree of importance in improving productivity in building construction projects on the scale of 1 to 5 .

\begin{tabular}{|l|l|l|l|l|l|}
\hline \multirow{2}{*}{ Best Practices for Construction Methods } & \multicolumn{5}{|c|}{ Level of Importance } \\
\cline { 2 - 6 } & $\begin{array}{c}\text { Not } \\
\text { important } \\
(1)\end{array}$ & $\begin{array}{c}\text { Slightly } \\
\text { importan } \\
(2)\end{array}$ & $\begin{array}{c}\text { Somewhat } \\
\text { important } \\
(3)\end{array}$ & $\begin{array}{c}\text { Very } \\
\text { important } \\
(4)\end{array}$ & $\begin{array}{c}\text { Extremely } \\
\text { important } \\
(5)\end{array}$ \\
\hline 1. Integrated Schedule & & & & & \\
\hline 2. Work Schedule Strategies & & & & & \\
\hline 3. Schedule Execution and Management & & & & & \\
\hline 4. Dynamic Site Layout Plan & & & & & \\
\hline 5. Traffic Control Plan & & & & & \\
\hline 6. Site Security Plan & & & & & \\
\hline 7. Machinery \& Equipment Positioning Strategy & & & & & \\
\hline 8. Project start-up plan & & & & & \\
\hline 9. Project Completion Plan & & & & & \\
\hline 10. Innovations \& New Technologies & & & & & \\
\hline
\end{tabular}

\section{B. Data Collection Tool from Building Projects}

B1. Project Characteristics

\begin{tabular}{|l|l|}
\hline Project type (residential, commercial etc.) & \\
\hline Project value & \\
\hline Floor area & \\
\hline Project start date: & \\
\hline Planned completion date: & \\
\hline Actual completion date: &
\end{tabular}

B2. Best Practices for Construction Methods Survey Tool(unweighted) (adapted from (CII, 2013b))

Please check $(\sqrt{ })$ one box per element in space provided in front of the level of implementation of the management practice. Please do not leave any elements blank.

\begin{tabular}{|l|l|}
\hline 1.Integrated Schedule \\
\hline Level A & The use of an integrated schedule using CPM is not applicable. \\
\hline Level B & The use of an integrated schedule using CPM has not been addressed. \\
\hline Level C & $\begin{array}{l}\text { Developing a schedule with no resources present and managing schedule status via duration or remaining } \\
\text { duration but not linked to earned percent complete progress from associated deliverables per activity. }\end{array}$ \\
\hline Level D & $\begin{array}{l}\text { Developing a schedule with resources present but no link to earned percent complete progress from } \\
\text { associated deliverables per activity. }\end{array}$ \\
\hline Level E & $\begin{array}{l}\text { Developing a schedule with resources present but not linked to earned percent complete progress from } \\
\text { associated deliverables per activity. Resources are updated to reflect current work content or quantity } \\
\text { adjustments. }\end{array}$ \\
\hline Level F & $\begin{array}{l}\text { Continuation of Level E and updated to include quantity adjustments. Earned progress for the activity is } \\
\text { based on measured or assessed work completed per deliverables per activity. Progress measurement } \\
\text { performed in application adapted specifically for each deliverable. }\end{array}$ \\
\hline
\end{tabular}

\begin{tabular}{|l|l|}
\hline 2. Work Schedule Strategies \\
\hline Level A & The development of a work schedule strategy is not applicable \\
\hline Level B & The development of a work schedule strategy has not been addressed \\
\hline Level C & $\begin{array}{l}\text { The strategy is based on a single work schedule be it either a straight time such as 36 hours per week schedule, } \\
\text { overtime, or other work schedule strategies. }\end{array}$ \\
\hline Level D & Strategy considers multiple work schedules considering critical and near critical activity sequences. \\
\hline Level E & $\begin{array}{l}\text { Continuation of Level D, plus strategies considers the potential impact on worker fatigue, supervision, safety, } \\
\text { and absenteeism. }\end{array}$ \\
\hline Level F & $\begin{array}{l}\text { Continuation of Level E, plus each potential strategy's impact is analysed for manpower density and } \\
\text { congestion at an area or sub-area level. }\end{array}$ \\
\hline
\end{tabular}




\begin{tabular}{|c|c|}
\hline \multicolumn{2}{|c|}{ 3. Schedule Execution and Management } \\
\hline Level A & The development of a schedule compliance plan is not applicable \\
\hline Level B & The development of a schedule compliance plan has not been addressed \\
\hline Level C & $\begin{array}{l}\text { Consistent follow-up to monitor the following tasks: schedule updated periodically, critical path analysis, and } \\
\text { progress narrative prepared as required and effective team participation in schedule updates. }\end{array}$ \\
\hline Level D & $\begin{array}{l}\text { Continuation of Level C, plus quantity reports are regularly performed. Upon request, or as the project } \\
\text { requires, may include any of the following: change management analysis, risks assessment scenarios/analysis, } \\
\text { date variance analysis to approved baseline or previous update period, start / finish percent achieved ratio } \\
\text { analysis, communication with material suppliers to ensure material will arrive on site when planned. }\end{array}$ \\
\hline Level E & $\begin{array}{l}\text { Continuation of Level D, plus monitor the following: schedule rigorously updated based on manual input of } \\
\text { quantity reports, critical and near critical path analysis, progress narrative prepared and effective team } \\
\text { participation in schedule updates. Quantity reports rigorously done by trained individual(s). Material suppliers } \\
\text { routinely contacted to track the status of material delivery dates. }\end{array}$ \\
\hline Level F & $\begin{array}{l}\text { Continuation of Level E, plus will consistently include all of the following, based on project requirements and } \\
\text { observed schedule status conditions: change management analysis, risks assessment scenarios/analysis, date } \\
\text { variance analysis to approved baseline or previous update period, start / finish percent achieved ratio analysis; } \\
\text { also included progress tracking using 3D imaging and other techniques. }\end{array}$ \\
\hline \multicolumn{2}{|r|}{ 4. Dynamic Site Layout Plan } \\
\hline Level A & Site layout plan is not applicable for the project. \\
\hline Level B & A site layout plan has not been addressed. \\
\hline Level C & $\begin{array}{l}\text { The project team examines the project schedule and assesses when Temporary Facilities (TF) will be brought } \\
\text { in. }\end{array}$ \\
\hline Level D & $\begin{array}{l}\text { Continuation of Level C, plus what sizes will be needed prior to the start of the project. No consideration is } \\
\text { given to the addition and removal of TFs at different stages of the project. No analysis is done in regards to } \\
\text { the layout of the project to optimize locations of the TFs to limit travel time to and from. }\end{array}$ \\
\hline Level E & $\begin{array}{l}\text { Continuation of Level D, plus consideration is given to the addition and removal of TFs at different stages of } \\
\text { the project. }\end{array}$ \\
\hline Level F & $\begin{array}{l}\text { Continuation of Level E, plus the team analyses the layout of the project including where the different parties } \\
\text { will be working and place their TFs in the optimum location in order to limit travel time to and from TFs. }\end{array}$ \\
\hline \multicolumn{2}{|r|}{ 5. Traffic Control Plan } \\
\hline Level A & Traffic control plans are not applicable for the project. \\
\hline Level B & Traffic control plans have not been addressed for the project. \\
\hline Level C & The project has some traffic control plans and is used on a reactive basis. \\
\hline Level D & $\begin{array}{l}\text { The project has a traffic control plan, equipment, and an arrangement for daylight traffic control only and has } \\
\text { no trained traffic control persons. }\end{array}$ \\
\hline Level E & $\begin{array}{l}\text { The project has a traffic control plan and equipment for all times of the day including trained persons for } \\
\text { traffic control. }\end{array}$ \\
\hline Level F & $\begin{array}{l}\text { Continuation of level E, plus a trained traffic control supervisor. It has an approved contingency plan in place } \\
\text { to accommodate unexpected situations, and has designed and constructed alternate arrangements for traffic } \\
\text { such as detours, flyovers, etc. }\end{array}$ \\
\hline \multicolumn{2}{|r|}{ 6. Site Security Plan } \\
\hline Level A & Site security plan is not applicable for the project. \\
\hline Level B & $\begin{array}{l}\text { The site does not institute security in regards to entry to the site, securing commodities, or tools and } \\
\text { equipment. }\end{array}$ \\
\hline Level C & The site controls entry and exit from the site, but does not have any other formal security throughout the site. \\
\hline Level D & $\begin{array}{l}\text { The site has established security procedures including visitor sign in and sign out procedure and security } \\
\text { guards at every gate. The site has implemented security measures to ensure the preservation of company } \\
\text { assets. Protocols have been identified for searches of individuals and their personal property. Searches are } \\
\text { conducted randomly. }\end{array}$ \\
\hline Level E & $\begin{array}{l}\text { Continuation of Level D, plus the site has ensured that material is not leaving the job site by instituting "lock- } \\
\text { ups" for items that are prone to theft. }\end{array}$ \\
\hline Level F & Continuation of Level E, plus the use of electronic security such as security cameras has been implemented. \\
\hline \multicolumn{2}{|r|}{ 7. Machinery Positioning Strategy } \\
\hline Level A & Machinery positioning strategy is not applicable. \\
\hline Level B & There is no strategy for positioning of machinery at the project site. \\
\hline Level C & $\begin{array}{l}\text { Heavy rigging and lifting studies are accomplished on all critical lifts including evaluation of the machinery, } \\
\text { rigging selection, and crane location. }\end{array}$ \\
\hline Level D & $\begin{array}{l}\text { Continuation of Level C, plus planning includes the use of } 2 \mathrm{D} \text { layout and studies to aid in constructability for } \\
\text { locating and utilizing machinery. }\end{array}$ \\
\hline Level E & $\begin{array}{l}\text { Continuation of Level D, plus some 3D modelling studies to aid in constructability for locating and utilizing } \\
\text { machinery. }\end{array}$ \\
\hline Level F & $\begin{array}{l}\text { Continuation of Level E, plus planning includes the use of 3D layout studies and 3D modelling/visualization } \\
\text { to aid in constructability for locating and utilizing machinery. }\end{array}$ \\
\hline \multicolumn{2}{|c|}{ 8. Project Start-up Plan } \\
\hline Level A & No start-up plan exists. \\
\hline Level B & communncated to the concerned stakenorder \\
\hline
\end{tabular}




\begin{tabular}{|c|c|}
\hline Level C & $\begin{array}{l}\text { A basic start-up plan has been developed with input from the project participants, but the plan has not been } \\
\text { implemented. }\end{array}$ \\
\hline Level D & $\begin{array}{l}\text { Continuation of Level C, plus with considerations for interfaces among sub-contractors or project } \\
\text { participants. A start-up plan has been developed that identifies the duties and responsibilities of each } \\
\text { stakeholder. }\end{array}$ \\
\hline Level E & $\begin{array}{l}\text { Continuation of Level D, plus with consideration for cost analysis and detailed scheduling components. The } \\
\text { plan is well communicated to all the stakeholders. }\end{array}$ \\
\hline Level F & $\begin{array}{l}\text { Continuation of Level E, plus with the plan being implemented on the project by incorporating feedbacks } \\
\text { from the stakeholders or project participants. }\end{array}$ \\
\hline \multicolumn{2}{|r|}{ 9. Project Completion Plan } \\
\hline Level A & The project completion requirement or handover procedure is not applicable. \\
\hline Level B & The project completion requirement or handover procedure has not been identified. \\
\hline Level C & $\begin{array}{l}\text { The project has a handover procedure that defines the parameters of project completion and delineates the } \\
\text { requirements for the handover. }\end{array}$ \\
\hline Level D & $\begin{array}{l}\text { The project has a formal handover process that defines the necessary documentation, parameters of } \\
\text { completion and other issues to assure proper handover of a project. }\end{array}$ \\
\hline Level E & Continuation of Level D, plus the procedure has been reviewed and agreed by the stakeholders. \\
\hline Level F & $\begin{array}{l}\text { Continuation of Level E plus the plan is approved by project management team and is reviewed for } \\
\text { applicability during all phases of the handover process. }\end{array}$ \\
\hline \multicolumn{2}{|r|}{ 10. Innovations and New Technologies } \\
\hline Level A & Innovation in new materials, equipment, information systems is not applicable. \\
\hline Level B & Innovations and new technologies investigation is not addressed. \\
\hline Level C & $\begin{array}{l}\text { The project does not have a formal program for the investigation of innovations and new technologies. } \\
\text { Implementation of innovations and new systems will only occur after the industry-wide implementation. }\end{array}$ \\
\hline Level D & $\begin{array}{l}\text { The organization has an informal program for the investigation of innovations, and they will investigate the } \\
\text { feasibility of the new technologies on a regular basis. }\end{array}$ \\
\hline Level E & $\begin{array}{l}\text { Continuation of Level D, plus the program is formal to investigate new systems and they will investigate the } \\
\text { feasibility of the new technologies on a regular basis. }\end{array}$ \\
\hline Level F & $\begin{array}{l}\text { Continuation of Level E, plus they investigate all new technologies using a formal system of rating the new } \\
\text { technology. }\end{array}$ \\
\hline
\end{tabular}

\section{Appendix-2}

Best Practices for Construction Methods Scoring Tool (Weighted) for Building Projects

\begin{tabular}{|c|c|c|}
\hline \multicolumn{2}{|c|}{ 1.Integrated Schedule } & \multirow{2}{*}{\begin{tabular}{|c|} 
Weights \\
0.00
\end{tabular}} \\
\hline Level A & The use of an integrated schedule using CPM is not applicable. & \\
\hline Level B & The use of an integrated schedule using CPM has not been addressed & 0.13 \\
\hline Level C & $\begin{array}{l}\text { Developing a schedule with no resources present and managing schedule status via duration or } \\
\text { remaining duration but no link to earned percent complete progress from associated deliverables } \\
\text { per activity. }\end{array}$ & 0.26 \\
\hline Level D & $\begin{array}{l}\text { Developing a schedule with resources present but no link to earned percent complete progress } \\
\text { from associated deliverables per activity. }\end{array}$ & 0.40 \\
\hline Level E & $\begin{array}{l}\text { Developing a schedule with resources present but no link to earned percent complete progress } \\
\text { from associated deliverables per activity. Resources are updated to reflect current work content or } \\
\text { quantity adjustments. }\end{array}$ & 0.53 \\
\hline Level F & $\begin{array}{l}\text { Continuation of Level E and updated to include quantity adjustments. Earned progress for the } \\
\text { activity is based on measured or assessed work completed per deliverables per activity. Progress } \\
\text { measurement performed in application adapted specifically for each deliverable. }\end{array}$ & 0.66 \\
\hline \multicolumn{3}{|c|}{ 2. Work Schedule Strategies } \\
\hline Level A & The development of a work schedule strategy is not applicable & 0.00 \\
\hline Level B & The development of a work schedule strategy has not been addressed & 0.15 \\
\hline Level C & $\begin{array}{l}\text { The strategy is based on a single work schedule be it either a straight time such as } 36 \text { hours per week } \\
\text { schedule, overtime, or other work schedule strategies. }\end{array}$ & 0.29 \\
\hline Level D & Strategy considers multiple work schedules considering critical and near critical activity sequences. & 0.44 \\
\hline Level E & $\begin{array}{l}\text { Continuation of Level D, plus strategies considers the potential impact on worker fatigue, } \\
\text { supervision, safety, and absenteeism. }\end{array}$ & 0.58 \\
\hline Level F & $\begin{array}{l}\text { Continuation of Level E, plus each potential strategy's impact is analysed for manpower density and } \\
\text { congestion at an area or sub-area level. }\end{array}$ & 0.73 \\
\hline \multicolumn{3}{|c|}{ 3. Schedule Execution and Management } \\
\hline Level A & The development of a schedule compliance plan is not applicable & 0.00 \\
\hline Level B & The development of a schedule compliance plan has not been addressed & 0.15 \\
\hline Level C & $\begin{array}{l}\text { Consistent follow-up to monitor the following tasks: schedule updated periodically, critical path } \\
\text { analysis, and progress narrative prepared as required and effective team participation in schedule } \\
\text { updates. }\end{array}$ & 0.31 \\
\hline
\end{tabular}




\begin{tabular}{|c|c|c|}
\hline Level D & $\begin{array}{l}\text { Continuation of Level C, plus quantity reports are regularly performed. Upon request, or as the } \\
\text { project requires, may include any of the following: change management analysis, risks assessment } \\
\text { scenarios/analysis, date variance analysis to approved baseline or previous update period, start / } \\
\text { finish percent achieved ratio analysis, communication with material suppliers to ensure material will } \\
\text { arrive on site when planned. }\end{array}$ & 0.46 \\
\hline Level E & $\begin{array}{l}\text { Continuation of Level D, plus monitor the following: schedule rigorously updated based on manual } \\
\text { input of quantity reports, critical and near critical path analysis, progress narrative prepared and } \\
\text { effective team participation in schedule updates. Quantity reports rigorously done by trained } \\
\text { individual(s). Material suppliers routinely contacted to track the status of material delivery dates. }\end{array}$ & 0.62 \\
\hline Level F & $\begin{array}{l}\text { Continuation of Level E, plus will consistently include all of the following, based on project } \\
\text { requirements and observed schedule status conditions: change management analysis, risks } \\
\text { assessment scenarios/analysis, date variance analysis to approved baseline or previous update period, } \\
\text { start / finish percent achieved ratio analysis; also included progress tracking using 3D imaging and } \\
\text { other techniques. }\end{array}$ & 0.77 \\
\hline \multicolumn{3}{|c|}{ 4. Dynamic Site Layout Plan } \\
\hline Level A & Site layout plan is not applicable for the project. & 0.00 \\
\hline Level B & A site layout plan has not been addressed. & 0.16 \\
\hline Level C & $\begin{array}{l}\text { The project team examines the project schedule and assesses when Temporary Facilities (TF) will be } \\
\text { brought in. }\end{array}$ & 0.33 \\
\hline Level D & $\begin{array}{l}\text { Continuation of Level C, plus what sizes will be needed prior to the start of the project. No } \\
\text { consideration is given to the addition and removal of TFs at different stages of the project. No } \\
\text { analysis is done in regards to the layout of the project to optimize locations of the TFs to limit travel } \\
\text { time. }\end{array}$ & 0.49 \\
\hline Level E & $\begin{array}{l}\text { Continuation of Level D, plus consideration is given to the addition and removal of TFs at different } \\
\text { stages of the project. }\end{array}$ & 0.65 \\
\hline Level F & $\begin{array}{l}\text { Continuation of Level E, plus the team analyses the layout of the project including where the } \\
\text { different parties will be working and place their TFs in the optimum location in order to limit travel } \\
\text { time to and from TFs. }\end{array}$ & 0.82 \\
\hline \multicolumn{3}{|c|}{ 5. Traffic Control Plan } \\
\hline Level A & Traffic control plans are not applicable for the project. & 0.00 \\
\hline Level B & Traffic control plans have not been addressed for the project. & 0.17 \\
\hline Level C & The project has some traffic control plans and is used on a reactive basis. & 0.34 \\
\hline Level D & $\begin{array}{l}\text { The project has a traffic control plan, equipment, and an arrangement for daylight traffic control } \\
\text { only and has no trained traffic control persons. }\end{array}$ & 0.511 \\
\hline Level E & $\begin{array}{l}\text { The project has a traffic control plan and equipment for all times of the day including trained } \\
\text { persons for traffic control. }\end{array}$ & 0.68 \\
\hline Level F & $\begin{array}{l}\text { Continuation of level E, plus a trained traffic control supervisor. It has an approved contingency } \\
\text { plan in place to accommodate unexpected situations and has designed and constructed alternate } \\
\text { arrangements for traffic such as detours, flyovers, etc. }\end{array}$ & 0.85 \\
\hline \multicolumn{3}{|c|}{ 6. Site Security Plan } \\
\hline Level A & Site security plan is not applicable for the project. & 0.00 \\
\hline Level B & $\begin{array}{l}\text { The site does not institute security in regards to entry to the site, securing commodities, or tools and } \\
\text { equipment. }\end{array}$ & 0.15 \\
\hline Level C & $\begin{array}{l}\text { The site controls entry and exit from the site, but does not have any other formal security } \\
\text { throughout the site. }\end{array}$ & 0.29 \\
\hline Level D & $\begin{array}{l}\text { The site has established security procedures including visitor sign in and sign out procedure and } \\
\text { security guards at every gate. The site has implemented security measures to ensure the preservation } \\
\text { of company assets. Protocols have been identified for searches of individuals and their personal } \\
\text { property. Searches are conducted randomly. }\end{array}$ & 0.44 \\
\hline Level E & $\begin{array}{l}\text { Continuation of Level D, plus the site has ensured that material is not leaving the job site by } \\
\text { instituting "lock-ups" for items that are prone to theft. }\end{array}$ & 0.59 \\
\hline Level F & $\begin{array}{l}\text { Continuation of Level E, plus the use of electronic security such as security cameras has been } \\
\text { implemented. }\end{array}$ & 0.73 \\
\hline \multicolumn{3}{|c|}{ 7.Machinery Positioning Strategy } \\
\hline Level A & Machinery positioning strategy is not applicable. & 0.00 \\
\hline Level B & There is no strategy for positioning of machinery at the project site. & 0.16 \\
\hline Level C & $\begin{array}{l}\text { Heavy rigging and lifting studies are accomplished on all critical lifts including evaluation of the } \\
\text { machinery, rigging selection, and crane location. }\end{array}$ & 0.33 \\
\hline Level D & $\begin{array}{l}\text { Continuation of Level C, plus planning includes the use of } 2 \mathrm{D} \text { layout and studies to aid in } \\
\text { constructability for locating and utilizing machinery. }\end{array}$ & 0.49 \\
\hline Level E & $\begin{array}{l}\text { Continuation of Level D, plus some 3D modelling studies to aid in constructability for locating and } \\
\text { utilizing machinery. }\end{array}$ & 0.65 \\
\hline Level F & $\begin{array}{l}\text { Continuation of Level E, plus planning includes the use of 3D layout studies and 3D } \\
\text { modelling/visualization to aid in constructability for locating and utilizing machinery. }\end{array}$ & 0.82 \\
\hline \multicolumn{3}{|c|}{ 8.Project Start-up Plan } \\
\hline Level A & No start-up plan exists. & 0.00 \\
\hline
\end{tabular}




\begin{tabular}{|c|c|c|}
\hline Level B & $\begin{array}{l}\text { A partial start-up plan has been prepared; the plan has not been communicated to the concerned } \\
\text { stakeholders. }\end{array}$ & 0.17 \\
\hline Level C & $\begin{array}{l}\text { A basic start-up plan has been developed with input from the project participants, but the plan has } \\
\text { not been implemented. }\end{array}$ & 0.34 \\
\hline Level D & $\begin{array}{l}\text { Continuation of Level C, plus with considerations for interfaces among sub-contractors or project } \\
\text { participants. A start-up plan has been developed that identifies the duties and responsibilities of each } \\
\text { stakeholder. }\end{array}$ & 0.51 \\
\hline Level E & $\begin{array}{l}\text { Continuation of Level D, plus with consideration for cost analysis and detailed scheduling } \\
\text { components. The plan is well communicated to all the stakeholders. }\end{array}$ & 0.68 \\
\hline Level F & $\begin{array}{l}\text { Continuation of Level E, plus with the plan being implemented on the project by incorporating } \\
\text { feedbacks from the stakeholders or project participants. }\end{array}$ & 0.85 \\
\hline \multicolumn{3}{|c|}{ 9.Project Completion Plan } \\
\hline Level A & The project completion requirement or handover procedure is not applicable. & 0.00 \\
\hline Level B & The project completion requirement or handover procedure has not been identified. & 0.17 \\
\hline Level C & $\begin{array}{l}\text { The project has a handover procedure that defines the parameters of project completion and } \\
\text { delineates the requirements for the handover. }\end{array}$ & 0.33 \\
\hline Level D & $\begin{array}{l}\text { The project has a formal handover process that defines the necessary documentation, parameters of } \\
\text { completion and other issues to assure proper handover of a project. }\end{array}$ & 0.50 \\
\hline Level E & Continuation of Level D, plus the procedure has been reviewed and agreed by the stakeholders. & 0.66 \\
\hline Level F & $\begin{array}{l}\text { Continuation of Level E plus the plan is approved by project management team and is reviewed for } \\
\text { applicability during all phases of the handover process. }\end{array}$ & 0.83 \\
\hline \multicolumn{3}{|c|}{ 10.Innovations and New Technologies } \\
\hline Level A & Innovation in new materials, equipment, information systems is not applicable. & 0.00 \\
\hline Level B & Innovations and new technologies investigation is not addressed. & 0.13 \\
\hline Level C & $\begin{array}{l}\text { The project does not have a formal program for the investigation of innovations and new } \\
\text { technologies. Implementation of innovations and new systems will only occur after the industry- } \\
\text { wide implementation. }\end{array}$ & 0.25 \\
\hline Level D & $\begin{array}{l}\text { The organization has an informal program for the investigation of innovations, and they will } \\
\text { investigate the feasibility of the new technologies on a regular basis. }\end{array}$ & 0.38 \\
\hline Level E & $\begin{array}{l}\text { Continuation of Level D, plus the program is formal to investigate new systems and they will } \\
\text { investigate the feasibility of the new technologies on a regular basis. }\end{array}$ & 0.51 \\
\hline Level F & $\begin{array}{l}\text { Continuation of Level E, plus they investigate all new technologies using a formal system of rating } \\
\text { the new technology. }\end{array}$ & 0.64 \\
\hline
\end{tabular}

